\title{
Effects of the Transfer of Rights and Jurisdictions on Mining Reclamation Performance in State Forest Areas in East Kalimantan
}

\author{
Rina Kristanti ${ }^{1 *}$, Hariadi Kartodihardjo ${ }^{2}$, Bramasto Nugroho $^{2}$, Irdika Mansur $^{3}$ \\ ${ }^{1}$ Graduate School in Forest Management Science, Faculty of Forestry and Environment, IPB University, Academic Ring Road, \\ Campus IPB Dramaga, Bogor, Indonesia 16680 \\ ${ }^{2}$ Department of Forest Management, Faculty of Forestry and Environment, IPB University, Academic Ring Road, Campus IPB \\ Dramaga, Bogor, Indonesia 16680 \\ ${ }^{2}$ Department of Silviculture, Faculty of Forestry and Environment, IPB University, Academic Ring Road, Campus IPB \\ Dramaga, Bogor, Indonesia 16680
}

Received November 29, 2019/Accepted July 13, 2020

\begin{abstract}
Mining is still considered to be an essential sector to gain national income and to provide energy supply. Forest Leasehold License (FLL) is a mechanism to accommodate the non-forestry sector, including mining development in the forest area. This license is a form of transfer of right given from Minister of Environment and Forestry to a mining license holder. Transfer of right by FLL contractual shaped jurisdictional boundary that is one of the obligations that has to be complied by FLL holder is to conduct mining reclamation. This study aimed to analyze the effects of FLL and its jurisdictional boundary on mining reclamation performance in East Kalimantan forest areas. It is a descriptive qualitative study based implemented the agency theory with the institutional approach. The study found that mining permit and FLL is a temporary transfer of right. The emerging problem in the FLL and its jurisdictional boundary related to asymmetric information and transaction cost caused moral hazards such as adverse risk selection of FLL holders by the principal, reclamation ignorance by the agent, and opportunism both from principal and agent. These agency problems affect FLL reclamation performance that just reached $41.35 \%$ over disturbed areas. Institutional challenges are due to the regulation gap creating a conflict of interest, budget and human resource constrain, cost center activity, and lack of economic incentive as well as lack of coordination among the government institutions. The research findings suggested inputs for institutional arrangement in terms of transfer of the right, including FLL reclamation process business, to improve its performance in the East Kalimantan forest area.
\end{abstract}

Keywords: Mining, forest, reclamation, institutional, agency

*Correspondence author, email: cumieinfahutan@gmail.com

\section{Introduction}

Article 38 of Forestry Law Number 41/1999 mandates the forestry sector to accommodate the development of the non-forestry sector, one of which is the mining sector. It is regulated in Government Regulation Number 105/2015 concerning FLL and elaborated through technical guidelines as most recently regulated through Minister of Environment and Forestry Decree Number 27/2018 concerning FLL Guidelines. The mining sector development within the forest area is carried out through an FLL scheme issued by the Minister of Environment and Forestry.

Budiawan et al. (2015) stated that forest areas managed by the government are embedded with the characteristics of common-pool resources (CPRs). These resources have a high inherent risk associated with the sub-tractability of forest services. Potential risks may occur through the struggle for community-based land access and control against forest managers. Schmid (1987) described the institutional arrangement interrelates with property rights, jurisdictional boundaries, and rules of representation.
Property rights are the right to use, generate income, or transfer rights to other parties (North, 1991). A party's property right is the authority to force the other party by limiting what the other party wants (Schmid, 1987). Jurisdictional boundaries are defined as authority held by a party to influence the other party (North, 1991). Rules of representation are sets of rules that determine the decisionmaking mechanism, such as rules for preference aggregation (Schmid, 1987).

One of the factors influencing the institutional management of natural resources is the regulatory framework (Ostrom, 1990; Fischer et al., 2007). Also stated by Kartodihardjo (1998), institutions are essential in regulating the actor's behavior, in which in CPRs management, the actor intends to have free-riding and rentseeking behavior. Theesfeld and Jelinek (2017) claimed that policy problems occurred by incentives commonly influence transaction costs, in particular, the implementation costs. Transaction costs, which include the costs of negotiation, monitoring, and enforcement, may be reduced through both 
formal and informal institutional arrangements that may increase the availability of well-distributed information and reduce barriers to supply in the economic market (Feiock, 2007).

Based on agency theory (Jensen \& Meckling, 1976), FLL contract is a transfer of rights that is granted by the Minister of Environment and Forestry as the mandate grantor called as principal to mining permit holder as mandate receiver called as the agent. Transfer of rights formed the jurisdiction boundary of the parties attached to the FLL contract. In this study, an institutional approach is implemented based focusing on its characteristic of transfer of rights and jurisdictional boundaries to describe mining reclamation as the consequences of FLL granting.

Zhang (2017) argued that the existence of mining reserves, robust industrialization, rapid development of government policies, and land utilization with its high sensitivity must be taken into account in preventing land degradation and promoting sustainable land management. If environmental impacts are not appropriately managed, ecological rehabilitation and post-mining land management will demand multiple human resources, infrastructures, and budgets. Therefore, environmental issues due to mining activities, especially in developing countries which their economy commonly rely on the mining sector, are becoming a global concern.

The mining companies must perform reclamation, and it is pivotal in the management of mining environmental impacts. This activity is an effort to restore the declining quality of land due to the negative externalities of mining practices in the forest area. Furthermore, the mining conflict cases in the forest areas are mainly resulted from poor licensing governance, causing conflicts between mining companies and private-owned forestry companies because of overlapping operational areas (Subarudi et al., 2016).

Chariri (2008) pointed out that agency analysis focuses on the relationship between the principal and the agent regarding incentives and costs incurred in carrying out contracts that generally govern the mechanism of incentive allocation, risk, compensation, and the choices of principals agents. There are at least two general problems in agency relations, namely: (1) asymmetric information specifically related to incentives and (2) differences in objectives between principal and agent.

The agency relationship's challenge is to achieve common goals of principal and agent (Jensen \& Meckling, 1976). As described by Zubayr et al. (2014), the transfer of rights stimulates the separation of authority between the principal and the agent. Principals with their limitations are more likely to employ ex-ante in terms of adverse selection risk by choosing the agent that is unable to fulfill contract obligations. Therefore, institutional development is required to improve the behavior of principal and agent. It is defined by Nugroho (2011) that institutions as rules aimed to control behavior in a way reducing potential opportunism.

Based on the conditions aforementioned above, one emerging idea is how the transfer of rights and jurisdictional boundaries influence mining reclamation performance in East Kalimantan forest areas. This study aimed to analyze the transfer of rights and jurisdictional boundaries and their effects on mining reclamation performance in East
Kalimantan forest areas. It provided inputs for improvements of Forest Leasehold License (FLL) reclamation performance as one of its contractual obligations towards sustainable forest management and good mining practice principles in forest areas. This paper discussed the transfer of right in FLL, CPRs characteristic of FLL reclamation area, actor's behavior in FLL reclamation business process, FLL reclamation performance, and the institutional development of FLL reclamation.

\section{Methods}

This research is a qualitative descriptive study (Creswell, 2016) developed based on principal-agent relationships (Jensen \& Meckling, 1976) within the scope of FLL transfer of rights and jurisdictional boundaries. The agency theory focuses on agency relationships in the form of transferring rights from the principal as the authorized owner to the agent as a mandate beneficiary. In this research, MoEF grants FLL that allows the mining license holder to carry out mining in the forest areas. This transfer of right positioned MoEF as the principal and FLL holder as the agent.

Data collection was carried out in JanuaryJune 2018 in East Kalimantan. This province plays a vital role in FLL reclamation. As stated by EITI (2016), East Kalimantan is notably the biggest export coal producer in 2016, contributing to $58 \%$ of national coal export. Indonesia's coal deposits in 2016 reached up to 28.5 billion tons, of which $25 \%$ of that was concentrated in East Kalimantan that lead this province as the second-largest coal concentration in Indonesia following South Sumatera (39\%). Besides, East Kalimantan is an area with the highest natural resources extraction industry compared to other provinces, as indicated by their share of the most top regional Gross Domestic Product. Regarding FLL, East Kalimantan is the largest mining area within the forest in Indonesia.

Data analysis employed qualitative descriptive methods using agency theory (Jensen \& Meckling, 1976). Primary data were obtained from in-depth interviews with informants from government agencies, FLL holders, academia, nongovernmental organizations, and local communities using snowball sampling techniques and field observations (Polit $\&$ Beck, 2012). Secondary data were obtained from content analyses of regulations and literature studies from FLL reclamation documents. Data and information covered the aspect of FLL contractual relationships, FLL reclamation business processes, and the role and authority of actors. Data analyses were carried out qualitatively through tabulation and descriptive methods implementing stakeholder analysis using 4R (right, revenue, responsibility, and relationship) by Dalal-Clayton et al. (2003), behavioral analysis (Chariri, 2008), and response analysis (Zubayr, 2014).:

\section{Results and Discussion}

Transfer of right in FLL In FLL contract, FLL holders must fulfill at least 18 obligations as agents to MoEF as FLL principal, namely: (1) to complete FLL boundary, (2) to submit FLL levy baseline, (3) to propose location for watershed rehabilitation, (4) to submit a notarial statement as a guarantee to compensate forest utilization by other party before FLL is granted, (5) to deliver the rights of third parties under local government facilitation, (6) to pay FLL levy as 
exchange of compensation land, (7) to conduct watershed rehabilitation with a ratio of 1:1 plus L3 area, (8) to convey state bank guarantee of 3 per 12 of estimated felling volume value based on timber cruising report, (9) to pay Provision of Forest Resources and/or Reforestation Funds, (10) to carry out reclamation and revegetation without waiting for the completion of FLL, (11) to maintain FLL boundary, (12) to conduct forest protection, (13) to reforest surrounding production forest area if FLL area technically cannot be reclaimed, (14) to employ Technical Officer of Sustainable Production Forest Management for Timber Testing, (15) to prevent forest damage, erosion, landslides and forest fires, (16) to empower local communities through the Forest Village Community Development Program and to employ Technical Officer of Social Management Sustainable in Production Forest Management, (17) to build public information related to environmental impact and community empowerment surround mining site, and (18) to submit work plan as FLL obligations no later than 100 working days after FLL issuance. From these, obligation (7), (10), (12), (13), (15), and (17) are directly related to the management of FLL impact on the forest.

Forest Leasehold License is a form of a contractual relationship between MoEF and FLL. In FLL transfer of the right, MoEF as the party that gives the mandate is positioned as the principal, whereas the FLL holder is the agent as the mandate receiver. When mining permit holders obtained an FLL, they automatically received rights and obligations based on the FLL contract. In FLL issuance, ex-ante requirements include: (1) Environmental Impact Assessment (EIA) and (2) commitment statements to submit the FLL levy baseline. Whereas in ex-post FLL contract, FLL holders must: (1) submit FLL reclamation plan and place FLL reclamation bond, (2) carry out FLL reclamation, and (3) pay FLL levy based on the size of the area and the magnitude of mining impact. Referring to Mineral and Coal Law Number 4/2009 and its derivative regulations, mining permit holders must carry out reclamation, including in forest areas, if mining activities are carried out in forest areas. The influence of agency relationship between mining company as FLL holder and MoEMR or Governor is that they must fulfill mining obligations mainly to recover mining impacts on the forest through reclamation. Ex-ante in mining reclamation obligations include: (1) to obtain EIA and its verification, (2) to submit reclamation plan and mine closure plan, (3) to place reclamation and post-mining bond, (4) to perform mining reclamation and mining closure and (5) to report reclamation progress through Annual Work and Budget Plan. Concerning those obligations, it is clearly described that reclamation and its business process is part of ex-ante and ex-post both in mining and FLL contractual relationship.
There are four types of rights in CPRs FLL bundle of right (Schlager and Ostrom 1992), namely: (1) access and withdrawal right, is the right to get access to extract mines and utilize forest products, (2) management right, is the right to determine the arrangement FLL area as stipulated in FLL contract, (3) exclusion right, is the right to exclude other parties who do not have access right in FLL contract, and (4) alienation, right is the right to transfer the FLL to another party. Based on the regulations governing FLL, regarding the bundle of right in FLL contract, there are three categories of the bundle of right in East Kalimantan involving five parties, namely: (1) owner, including MoEF as FLL holder, (2) proprietor, including FLL holder and Timber Utilization License (TUL) holder, and (3) local community surround FLL areas as a user in forest resource utilization. The types of the bundle of right in FLL contract in East Kalimantan are summarized in Table 1.

Transfer of right through FLL scheme for mining activities in East Kalimantan reached 90 units of 143804.89 ha that spread across six districts: Kutai Barat, Kutai Timur, Kutai Kartanegara, Paser, Penajam Paser Utara, and Berau. Mining license can be issued by MoEMR, Governor or Head of District/Municipality based on their authority stated in Mineral and Coal Law Number 4/2009. The 90 FLL units consisted of 34 units of mining permit issued by MoER covering 92,010.73 ha. The other 56 FLL units are holders of mining permits issued by East Kalimantan Governor and Head of Districts, covering 51,794.16 ha. Kutai Timur has the largest FLL area of 42,809.19 ha. The distribution of FLL based on the type of mining permit in East Kalimantan is shown in Table 2.

CPRs characteristic of forest leasehold license area CPRs characteristic are generally characterized by subtraction, joint impact goods, and non-excludability (Kartodihardjo, 2006). Subtractability is the condition when the utilization of a resource will diminish its availability to the other party. Joint impact good is the resource when it is utilized by one party; another party will not be able to utilize the resource. Non-excludability occurs when there are difficulties in excluding the non-entitled party in utilizing the resource. Furthermore, German and Keeler (2010) categorize forest resources as CPRs with non-excludability characteristics. It is challenging to define property rights clearly so that it requires a set of institutionalized rules to regulate the behavior of its users.

Forest resources with characteristics of CPRs are regulated in Forestry Law Number 41/1999. In Article 4, it is described that all forests in the Republic of Indonesia's territory, including the natural resources contained therein, are controlled by the state for the people's welfare. The state

Table 1 Type of bundle of right in forest leasehold license in East Kalimantan

\begin{tabular}{lccc}
\hline Type of right & The owner (MoEF) & Proprietor (FLL and TUL holders) & User (community) \\
\hline Access and withdrawal & $\times$ & $\times$ & $\times$ \\
Management & $\times$ & $\times$ & \\
Exclusion & $\times$ & $\times$ & \\
Alienation & $\times$ & & \\
\hline
\end{tabular}


Table 2 The state of mining forest leasehold license in East Kalimantan

\begin{tabular}{|c|c|c|c|c|c|c|}
\hline \multirow[t]{3}{*}{ District } & \multicolumn{4}{|c|}{ Type of mining permit } & \multirow{2}{*}{\multicolumn{2}{|c|}{$\begin{array}{l}\text { Forest leasehold } \\
\text { license }\end{array}$}} \\
\hline & \multicolumn{2}{|c|}{ by MoEMR } & \multicolumn{2}{|c|}{ by governor/head of district } & & \\
\hline & Unit & Area (ha) & Unit & Area (ha) & Unit & Area (ha) \\
\hline Kutai Barat & 6 & $22,519.13$ & 16 & $14,103.51$ & 22 & $36,622.64$ \\
\hline Kutai Timur & 7 & $32,425.95$ & 5 & $10,383.24$ & 12 & $42,809.19$ \\
\hline Kutai Kartanegara & 15 & $18,100.76$ & 24 & $21,245.64$ & 39 & $39,346.40$ \\
\hline Penajam Paser Utara & - & - & 2 & 189.08 & 2 & 189.08 \\
\hline Paser & 1 & $11,975.66$ & 3 & $1,865.16$ & 4 & $13,840.82$ \\
\hline Berau & 5 & $6,792.67$ & 6 & $4,204.09$ & 11 & $10,996.76$ \\
\hline Total & 34 & $91,814.17$ & 56 & $51,990.72$ & 90 & $143,804.89$ \\
\hline
\end{tabular}

authorizes the government in this term is the Ministry of Forestry (currently the Ministry of Environment and Forestry) to regulate and manage the forest, forest areas, and its products. The activity of forest management includes managing FLL to accommodate the development of the nonforestry activity, mining in the state forest.

Mining permit and FLL is a temporary transfer of rights that are given for a period that is the same as mining lifetime. In the case of the FLL, its area is CPRs with its inherent characteristic of non-excludability and sub-tractability that trigger nontrivial problems in CPRs management. Furthermore, the exclusion of multiple users in CPRs utilization is difficult and costly as the consumption is rival (Ostrom et al., 1994). The issuance of FLL transfers access and withdrawal, management and exclusion rights from MoEF to FLL holder. It limits other parties to have those rights of the FLL area.

Some FLL areas have been utilized by the community surrounding the forest area before FLL is granted. As one of the most important and valuable natural resources, land contributed to conflict between FLL holders and the community caused by the access to utilize the forest land. Based on some EIA documents of FLL holders, the surrounding community in FLL area utilized forest land for paddy fields, planting cassava, vegetables, rubber, coconut, fruit, or resin wooden tree or other species with economic value. They even hunt in the forest for food supply. Once FLL is released, the community that utilizes forest function does not have access to the forest as the character of CPRs as joint impact goods. The community must look for alternative sources of livelihood, including working in FLL company and trading and selling things to mining workers, including providing the revegetation service to the FLL company. Those conditions imply the case of primitive accumulation. Hein (2019) stated that primitive accumulation occurs when the previous users of the land are displaced or unable to continue their activities and are consequently forced to sell their labor to the land manager.

Contrarily, overlapped use of forest land generated exclusion costs incurred by FLL holders. Without any indemnity as exclusion cost, the impacted community would not move, and mining activity cannot be conducted. Even though forest land managed by MoEF, in the field, the community managed the forest and sometimes supported by the land certificate. The land is owned by clearing the forests, buying from other parties, and hereditary from parents. Based on the ownership, people can change their ownership, lend, moreover, transferred to others by selling. As an example, one of the mining permits issued by MoEMR that holds 2 FLL units (21 and 22) in the Kutai Barat District, there are communities in the FLL area utilized the forest for resin and rattan collection, hunting, and farming before FLL is granted. Exclusion cost is required to move the community, and FLL holders cannot start the operation if the deliberations on indemnity value have not been agreed between both parties. To anticipate potential conflicts in the future, in land acquisition, FLL holder coordinated with the district, subdistrict, and village governments.

The problems commonly occurred in land acquisition related to high indemnity rate, unclear administrative boundaries, and overlapped land tenure among parties. This case also happened in the FLL holder in Kutai Kartanegara District. The value of forest land greatly varied based on land conditions. Certified land ranged from IDR155,333 million $\mathrm{ha}^{-1}$ and IDR111,155 million $\mathrm{ha}^{-1}$ for uncertified land. The land certification was granted by the Land Certification Officer (Pejabat Pembuat Akta Tanah/PPAT), mostly the Head of Sub-District. The presence of land speculators also influenced the amount of exclusion cost. One mining permit holder issued by MoEMR holds 3 FLL units (Unit 59, 60, and 61 ) in Kutai Kartanegara District spent exclusion cost up to IDR400 million ha ${ }^{-1}$.

The community has existed before FLL issuance. They mostly utilized the forest area for agriculture activity. Indemnity is the solution preferred by the FLL holder to ensure business continuity. One case in Kutai District is one of the mining permits issued by MoEMR with 2 FLL units ( 80 and 81) in the Kutai District. FLL holder gave it to the community witnessed by Head of Sub-District. This condition is prevalent in FLL holders and community relationships. It was caused by a lack of approach from the mining company to the community in particular in EIA public consultation as well as the opportunism behavior of community once they got the information about mining operation plan in the forest area. Another case occurred in one mining permit issued by MoEMR that has 2 FLL units in Kutai Kartanegara District. The forest area they compensated covered $100 \%$ of the 700 ha FLL area, 1,150 ha out of 1,850 ha FLL area, $100 \%$ of 900 ha FLL area, and 1,000 ha out of 1,200 ha FLL area. 
Related with reclamation, the occurring problem in FLL transfer of right in East Kalimantan between FLL holder and community also related to the community's interventions on FLL reclamation. In Kutai Barat District, some of the communities requested that the FLL holder conduct reclamation by planting crops, multipurpose tree species (MPTS), and even oil palm. MoEF Decree Number P.60/2009 concerning Guidelines for Evaluation of Forest Reclamation has accommodated the community's need for MPTS to a maximum of $60 \%$ of the plantation. They requested the whole reclamation area to be planted by agricultural or other species that made would make reclamation could not meet the minimum criteria for successful reclamation. That species cannot meet the criteria based on MoEF Decree Number P.60/2009 that stated the reclamation land should be replanted using local species, respectively, $40 \%$ of the total area where the other $60 \%$ can be planted using MPTS or fast-growing species. The use of non-timber or crop species, including oil palm, is allowed as long as replantation can meet that criterion.

Also, some FLL holders have empowered the local community through a nursery program for FLL reclamation. The obstacle that occurred was that they were unable to meet seed quality criteria due to the lack of capacity. Another challenge is that the reclaimed area that has been partially returned to MoEF was still under FLL holder responsibility. The occupancy by the community on the reclamation area became a disincentive for FLL holders. They spent a large amount on security costs to keep their reclamation area. In Kutai Kartanegara and Kutai Barat Districts, occupancy occurred both in the FLL area that had or had not been returned to MoEF. The community demands that FLL holders accommodate their desire to use FLL reclamation land for oil palm plantations. If the request is accommodated, the FLL reclamation activity cannot meet the FLL reclamation success criteria. Problems with the community also created a technical problem in FLL reclamation due to revegetation and caused the reclamation area cannot be returned to MoEF. Thus, FLL holders have to pay FLL levy based on its damage magnitude. In conclusion, exclusion and coordination costs to cope with community problems increased operational cost and indirectly affected reclamation performance.

The challenge in FLL transfer of rights was related to the negative impact of mining on the forest in the case of subtractability. Based on the regulation in managing FLL contractual, FLL holders have to compensate for the opportunity cost of forest function damaged by temporary mining activity in forest areas through FLL levy. The aim is to control the development of FLL, especially for mining. Although mining is a temporary land use activity, it is challenging to accurately assess mining impact (Zhang et al., 2017). The tariff of FLL levy is imposed on all FLL area according to the criteria for their use, including: (1) L1 criteria (area for active mine opening, infrastructure facilities and buffer area); (2) L2 criteria (an area that can be technically reclaimed); and (3) L3 criteria (an area that has permanent damage after reclamation is conducted but cannot be recovered optimally). Once the FLL holder performs the reclamation evaluated by MoEF and accepted, the burden of FLL levy is minimized.
Transfer of right by FLL also triggered transaction cost in terms of coordination cost between FLL holder and TUL holder. Based on MoEF Decree Number P.27/2018 in Article 10 , mining in forest areas can be accommodated through the FLL scheme and can be carried out in production forest areas that have been encumbered by TUL. Along with rapid FLL development after 2006 as a result of Minister of Forestry (MoF) Decree Number P.14/2006 concerning Guideline for FLL as the first ministerial regulation in FLL issuance. One aspect regulated through the decree was FLL can be issued in the TUL area as long as FLL holder obtained a letter of acceptance from the TUL holder. This condition triggered business-to-business (B to B) dealing between TUL and FLL holders. However, the number of FLL in the TUL area disrupted the work plan and TUL business entity. As a solution, the government released MoF Decree Number 16/2014 concerning Guideline for FLL, where Article 11 paragraph (1) stipulated the FLL area that is encumbered with TUL area can be considered at most $10 \%$ of TUL effective area. In relation transfer of the right of FLL that were mainly in production forest areas, there are several FLL located in the TUL area both in natural production forest and plantation forest. There were 18 units of TUL in natural production forest used by 22 FLL units, whereas 37 FLL units used plantation forest and 22 TUL units. In total, 51 units of FLL ( 15 units have expired) are located in 40 units of natural production and plantation TUL in East Kalimantan.

As information from several FLL holders, the coordination cost of FLL in terms of investment substitution affected FLL mining cost structure. One of the FLL holders in Kutai Barat District was not able to conduct mining operations since there was no agreement on substitution of the amount determined by the TUL holder, which reached billion rupiahs. For sure, it affected the financial capacity of FLL holders, especially the one that holds a mining permit issued by Governor or Head of District that generally has limited capital compared with one issued by MoEMR that is usually a multi-national company.

In 2007, one mining permit holder issued by MoEMR in Berau District paid forest investment indemnity to TUL holder. The FLL unit provided USD 5 million for an area of 3,582.13 ha or equal with USD1,396 ha ${ }^{-1}$ for FLL lifetime. However, in addition to this indemnity, FLL holders must also provide supervision fees to TUL holders of USD1.4 ton $^{-1}$ of coal produced by FLL holders. Eventually, none of the indemnities went to MoEF as TUL's principal. Opportunism occurred from the TUL holder in the form of rent-seeking behavior. It gained income from FLL holder on state forest under MoEF authority managed by TUL holder through TUL contract.

As Zubayr (2014) described, one FLL holder in South Kalimantan was required to compensate IDR66.53 billion year $^{-1}$ to TUL holder for joint use of $3 \mathrm{~km}$ logging roads. Based on the bundle of rights defined by Schlager and Ostrom (1992), even though TUL holder had the same position as an agent to MoEF like FLL holder, the implementation of fees and indemnity positioned TUL holder as a principal of FLL holder. However, this dispute was a moral hazard of the TUL holder. The dispute of investment indemnity from FLL holder to TUL holder is tackled by MoEF Decree Number P.27/2018 article 43. The 
indemnity of forest investment still based on business as usual of the agreement from both parties.

The FLL reclamation result is a potential asset to be developed by the East Kalimantan Government. As regulated through MoEF Decree Number 27/2018, Article 66 that when FLL terminated, forest stands in FLL reclamation become MoEF's property. In Article 67, it is also regulated that FLL holder must hand over FLL reclamation areas that are not encumbered with TUL or any other forest utilization license to Forest Agency to be managed by Forest Management Unit (FMU) under the agency. Based on East Kalimantan Governor Decree Number 39/2019 concerning Formation and Organization of Technical Implementation Units in East Kalimantan Forestry Agency, there are currently 22 FMU units in East Kalimantan. 18 FMUs have been institutionalized, and 4 FMU have not been formed as an institution. From 18 FMU, 16 units are Production FMU, while the other two units are Protection FMU. From the study of Long Term Forest Management Plan (LTFMP) of these units, only 8 Production FMU units, namely Berau Barat, Meratus, Bongan, Delta Mahakam, Kendilo, Santan, Telake, and Belayan already have an approved LTFMP. However, 8 Production FMU units and two other Protection FMU units are still in process. From 8 FMU units with LTFMP, five units, namely Berau Barat, Santan, Belayan, Meratus, and Kendilo, have FLL activity inside their management area.

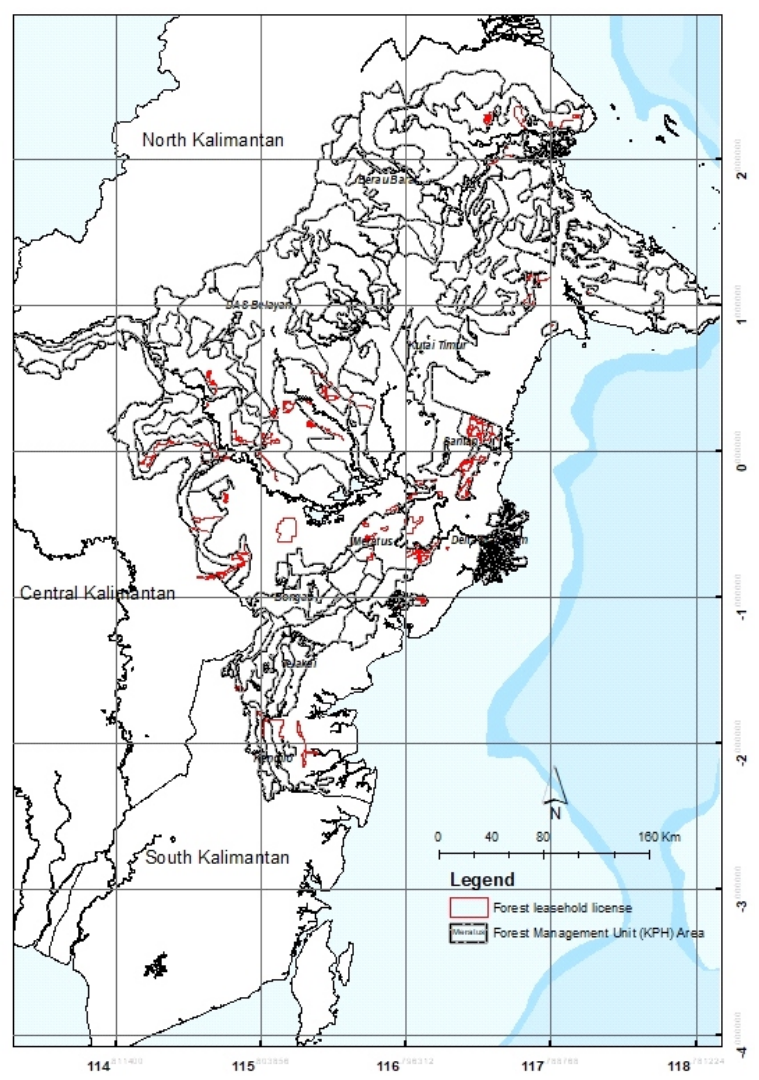

Figure 1 Map of forest leasehold license distribution in forest management units.
The distribution of FLL in FMUs in East Kalimantan is presented in Figure 1.

From 90 FLL units, only 51 units have been recorded in approved FMU LTFMP, while 39 units (most of which 20 units are in Kutai Barat District) are still in process. In the effort to utilize the FLL reclamation area, FMU units do not yet have strategic plans in the utilization and business development of the FLL reclamation area. Only FMU Delta Mahakam in Kutai Kartanegara District has no FLL for mining, developing a plan to develop a plantation TUL scheme. As some FLL holders have developed reclamation utilization in non-forest land through silvopasture, cage fisheries, and agroforestry, FMU units do not seem to focus on business development for it. The gap of coordination and asymmetric information between FLL holders and FMU managers, as well as less authority of the FMUs, is caused by regulation. It constrained an optimum development of reclamation performed in the FMU management site.

Currently, no regulation provides incentives for FLL holders who interest in developing FLL reclamation through non-forestry activity. Some of the non-forestry activities are successfully developed by FLL holders like silvopasture, non-timber plantation for essential oil production, fisheries, and clean water production as part of reclamation efforts in the non-forestry area. One FLL holder in Berau District succeeded in lemongrass and cajuput oil production with potential economic value as income generation beneficial to support FMU business development once the FLL area is returned to the government. This FLL holder also succeeded in goat and cow breeding to support food security in Berau District. As stated by the field manager in the company's silvopasture development, regarding food supply distribution, Berau District is a distanced district compared with other districts in the province. Thus, this area slightly has a deficit in animal protein supplies and still highly depends on other region's supplies such as Java and Sulawesi Islands. The development of silvopasture is a promising alternative to support food security in the district. However, the development of non-forestry activities like silvopasture and non-timber plantation in the FLL reclamation area would not follow the criteria for successful FLL reclamation mandated by MoF Decree Number P.60/2009. This regulation is stiff to innovation in converting reclamation from a cost center activity into a profit center. Future utilization of FLL reclamation will be directed to the development of social forestry schemes, although in the meantime, it is not implementable yet in the field. Innovation in regulation to make it more flexible is urgently required to provide an incentive not only for FLL holders but also for FMU as the beneficiary of FLL reclamation.

Actor's behavior in FLL reclamation business process Based on the results of the $4 \mathrm{R}$ analysis (Dalal-Clayton et al., 2003) concerning 27 regulations governing the FLL reclamation business process, FLL reclamation involved various actors and their relationships as presented in Figure 2.

Figure 2 illustrates the flow of contractual relationships in mining permit and FLL business processes. Black arrows present relationship in mining permit and FLL process, and 


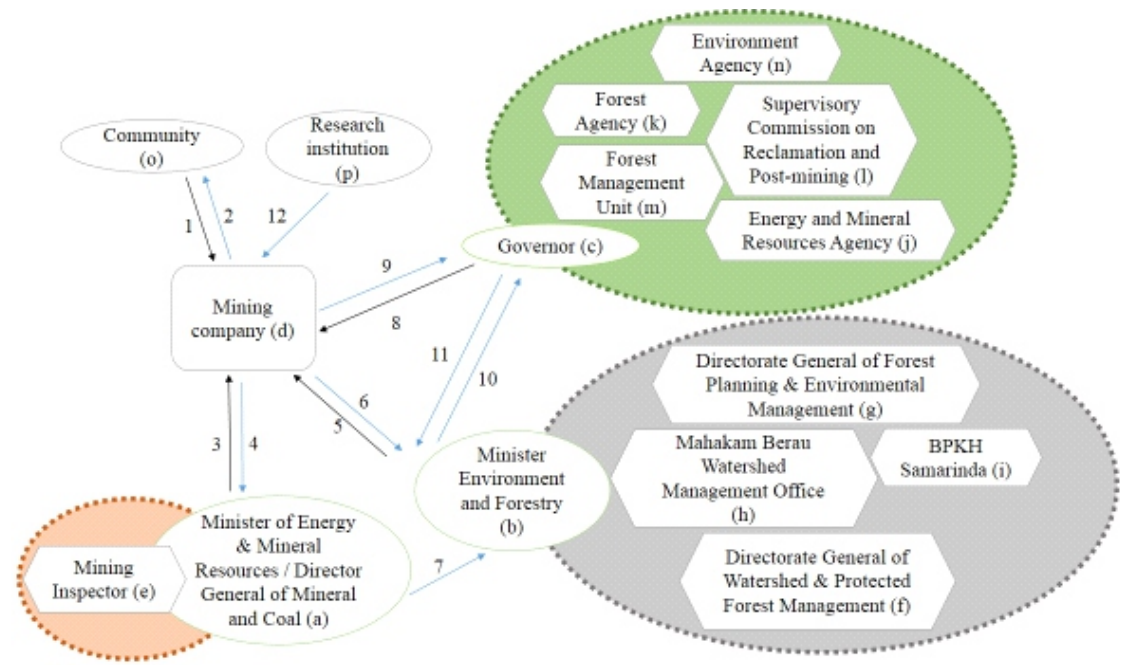

Figure 2 Contractual relationship in forest leasehold license in East Kalimantan.

blue arrows indicate mining and FLL reclamation obligations as consequence mining and FLL contractual relationship. The flow is described as follows:

1. Arrow 1 presents community support in the EIA process as requirements to propose mining permit;

2. Arrow 2 presents reclamation obligation to minimize mining impact to the community;

3. Arrow 3 and 8 present mandates from MoEMR or Governor in term of mining permit issuance;

4. Arrow 4, 6 and 9 present mining and FLL reclamation obligation as stipulated in mining permit and FLL contract;

5. Arrow 5 presents FLL granting from MoEF to the mining license holder;

6. Arrows 7 and 11 present obligations conducted by MoEMR or Governor to involve MoEF and its technical office in East Kalimantan in reclamation plan evaluation;

7. Arrow 10 presents mandate transfer from MoEF to FMU on behalf of Governor to manage FLL reclamation assets invested by FLL holder;

8. Arrow 12 presents the involvement of independent research institutes as part of the FLL reclamation evaluation team.

One of the actors who have an interest in reclamation but is not included in the mining permit nor FLL reclamation business process is the National Movement to Save Natural Resource initiated by Corruption Eradication Commission (CEC). The evaluation result of this movement is that reclamation faced data and information systems problems, imposing good mining practice based on Mineral and Coal Law Number $4 / 2009$, and reporting obligations. The actors' behavior improved by this movement through Coordination and Supervision on Mineral and Coal, which has been carried out in East Kalimantan in 20142016. The supervision spurred the commitment of East Kalimantan governments in sharpening their authority, including the reclamation business process as mandated by Local Government Law
Number 23/2014. Their commitment is shown by the activation of the Supervisory Commission on Reclamation and Post-mining. East Kalimantan is the only province in Indonesia having this institution aimed to ensure mining permit holders properly conduct mining reclamation and its business process. The commitment of MoEMR was also 137 improved due to the enforcement of the supervision. It was evidenced by improved commitment of mining companies in fulfilling reclamation plans, reclamation bonds, and reclamation implementation as well as its reporting. From the analysis of the ex-ante and ex-post implementation of FLL contractual FLL related to FLL reclamation, the behavior of relevant actors is summarized as in Table 3.

Forest leasehold license reclamation performance To internalize negative externalities of mining activities, the governments have issued various regulations governing mining reclamation. Mining permit and FLL holder is obligated to conduct reclamation to improve the quality of the environment in disturbed forest areas without waiting for the completion of FLL. The implementation of FLL reclamation in East Kalimantan challenged: (1) voids are not immediately reclaimed at the time FLL ends, (2) soil management, such as the difficulty of soil separation in backfilling, topsoil is very thin with high acidity, (3) revegetation is sub-optimal due to lack of soil analysis before reclamation is conducted, lack of planting the long-cycle local plants and minimal maintenance, (4) sob-optimal soil conservation infrastructure causing erosion and sedimentation, (5) lack of forestry personnel in mining environment division, (6) ignorance of reporting obligations and (6) lack of protection for reclamation areas making them vulnerable to illegal logging and mining, and fire.

In this study, FLL reclamation performance is defined based on the FLL reclamation business process, reclamation costs, reclamation development based on location, and FLL response based on the mining permit type. Mining 
Table 3 Actors' behavior in the forest leasehold license business process

\begin{tabular}{|c|c|}
\hline Actor & Behavior \\
\hline $\mathrm{a}$ & $\begin{array}{l}\text { Did not involve MoEF in reclamation plan evaluation of mining permit released by MoEF; lacked } \\
\text { coordination with Energy and Mineral Resource Agency; lack of commitment in reducing conflict of } \\
\text { interests between Mining Inspector and mining permit holder in reclamation evaluation; lack of } \\
\text { commitment in sanction enforcement to the mining company that irresponsible of reclamation; improved } \\
\text { commitment after supervision; did not synchronize criteria for reclamation evaluation based on FLL } \\
\text { reclamation criteria; sub-optimal determination of reclamation bond value; and opportunism in the } \\
\text { reclamation evaluation process. }\end{array}$ \\
\hline $\mathrm{b}, \mathrm{g}$ & $\begin{array}{l}\text { Did not enforce the obligations of FLL reclamation plan and reclamation bond as FLL obligation; did not } \\
\text { facilitate FLL incompatibility with community nor TUL holder; sub-optimal in FLL levy verification; and } \\
\text { did not enforce sanctions for FLL levy and reclamation neglection by FLL holders. }\end{array}$ \\
\hline $\mathrm{b}, \mathrm{f}$ & $\begin{array}{l}\text { Did not enforce the obligations of FLL reclamation plan and reclamation bond; did not commit to reducing } \\
\text { conflicts of interest and fungibility by stating reclamation target in the strategic plan to support budgeting } \\
\text { and reducing fungibility; did not enforce sanctions to FLL holders that neglecting reclamation obligations; } \\
\text { sub-optimal in evaluating reclamation; opportunism in layered stages of reclamation evaluation and } \\
\text { watershed rehabilitation; and lack of coordination with Directorate General of Forestry Planning and } \\
\text { Environmental Management related to FLL levy baseline and Mahakam, Berau Watershed Management } \\
\text { Office, related to monitoring data updating. }\end{array}$ \\
\hline $\mathrm{c}, \mathrm{j}$ & $\begin{array}{l}\text { Lack of commitment in reducing conflict of interests between Mining Inspector and mining permit holder in } \\
\text { reclamation evaluation, lack of FMU's involvement FMU, sub-optimal determination of reclamation bond } \\
\text { value, lack of coordination with Supervisory Commission on Reclamation and Post-Mining, improved } \\
\text { commitment after supervision, involved MoEF Technical Office in East Kalimantan. }\end{array}$ \\
\hline $\mathrm{c}, \mathrm{k}$ & Lack of support to enhance the FMU role in FLL reclamation. \\
\hline 1 & $\begin{array}{l}\text { Sub-optimal in authority implementation due to budget constraints, improved commitment after the } \\
\text { supervision, lack of independence since its authority depends on governor interest. }\end{array}$ \\
\hline $\mathrm{e}$ & $\begin{array}{l}\text { Sub-optimal in authority implementation due to budget constraints, improved commitment after the } \\
\text { supervision, opportunism in the reclamation evaluation process. }\end{array}$ \\
\hline h, i & $\begin{array}{l}\text { Sub-optimal in FLL levy verification and reclamation monitoring and evaluation due to budget constrain, } \\
\text { opportunism in the reclamation evaluation process. }\end{array}$ \\
\hline $\mathrm{d}$ & $\begin{array}{l}\text { Intend to have asymmetric information, risk-averse and opportunism behavior in every process of FLL } \\
\text { reclamation business process, improved commitment after CEC supervision, placed voids in the non-forest } \\
\text { area. }\end{array}$ \\
\hline o & Occupancy and encroachment causing high exclusion cost \\
\hline $\mathrm{p}$ & Became a passive party in FLL reclamation evaluation \\
\hline
\end{tabular}

performance based on the FLL reclamation business process is presented in Table 4.

Mining permit and FLL imposed mining company to perform reclamation and encounter its success criteria regulated through MoEF Decree Number P.60/2009 and Director General of Mineral and Coal Decree Number 1827/2018 concerning Guideline of Good Mining Practice. Reclamation cost became a consequence for FLL holders to achieve those criteria. As confirmed by Ai-Bin et al. (2009), the cost of environmental management in natural resource utilization is mostly allocated to compensate and reduce the impact of environmental damage. The number of reclamation costs for some FLL holders is outlined in Table 5.

The MoEF has issued 90 FLL units in East Kalimantan covering $143,804.89$ ha. The total disturbed area is $37,679.98$ ha with reclamation progress reached $15,582.36$ ha $(41.35 \%)$ and revegetation $1,215.20$ ha $(3.22 \%)$. This performance is considered as a low performance of reclamation that by regulation, it is managed that reclamation covered revegetation activity to restore forest function. The low reclamation performance represents low responsibility in FLL transfer of right as reclamation is part of the obligations in FLL contracts. The FLL reclamation performance is presented in Table 6.

From 90 FLL units in East Kalimantan, there are 68 units whose FLL are still active, both in disturbed areas and those having not started mining operations. From 68 active FLL, there are 35 units conducting mining, and 33 units have not conducted operation yet. Total FLL area of those 35 active units reached 78,114.11 ha with disturbed areas of 36,767.41 ha. Progressive reclamation performance was $13,918.25$ ha $(40.80 \%)$ and revegetation $1,193.57$ ha $(3.25 \%)$. The progressive performance indicated the reclamation obligation performance of 35 active FLL units that still run their mining activity until the year 2042. Permanent performance with FLL expiration until 2018 is within 22 FLL units consisting of 7 units have conducted mining operation with total FLL area reached 14,321.86 ha and disturbed area reached 912.57 ha whereas 15 other units have not conducted mining operation. Permanent reclamation performance reached 580.99 ha $(63.67 \%)$ and revegetation performance reached 21.63 ha $(2.37 \%)$.

The reclamation progress of the mining permit issued by MoEMR is higher than that issued by the East Kalimantan Government. As stated by Maharani et al. (2010), mining permits issued by MoEMR which are commonly large transnational mining companies, generally have higher 
Table 4 Reclamation performance based on reclamation business process

\begin{tabular}{ll}
\hline \multicolumn{1}{c}{ Aspect } & \multicolumn{1}{c}{ Performance } \\
\hline Reclamation plan & $\begin{array}{l}\text { Before CEC supervision, RP obligation was improperly implemented by the mining } \\
\text { permit holder issued by the East Kalimantan Government. From 56 FLL units, only 35 } \\
\text { units }(62.50 \%) \text { submitted RP, but 22 units of those did not on time. After supervision, } \\
\text { from those 22 units, 11 units submitted RP on time. From 34 FLL units holding mining } \\
\text { issued by MoEMR, 31 units (91.18\%) submitted RP. }\end{array}$ \\
\hline Reclamation bond & $\begin{array}{l}\text { 1. } \\
\text { (RB) }\end{array}$ \\
thefore CEC supervision, RB amount and its placement were not optimum, especially \\
supervision, it increased by 11 FLL units holding mining permits issued by East \\
Government placed RB.
\end{tabular}

Table 5 Reclamation costs in Berau District

\begin{tabular}{|c|c|c|c|c|}
\hline \multirow[t]{2}{*}{ Cost allocation } & \multicolumn{4}{|c|}{ Cost (IDR ha ${ }^{-1}$ ) } \\
\hline & \multicolumn{2}{|c|}{$\begin{array}{l}\text { (mining permit issued by East } \\
\text { Kalimantan G overnment) }\end{array}$} & \multicolumn{2}{|c|}{$\begin{array}{c}\text { (mining permit issued by } \\
\text { MoEMR) }\end{array}$} \\
\hline \multicolumn{5}{|l|}{ Direct cost } \\
\hline - Soil and land management cost & $31,614,388$ & $27,500,690$ & $104,836,305$ & $105,338,896$ \\
\hline - Revegetation cost & $7,376,251$ & $19,008,415$ & $37,579,965$ & $37,760,155$ \\
\hline - Acid mine drainage management cost & $27,447,998$ & $9,889,780$ & $4,245,369$ & $36,980,849$ \\
\hline - Void management cost & - & $11,108,409$ & 404,341 & - \\
\hline Indirect cost & $9,965,796$ & $6,413,193$ & $27,942,539$ & $34,215,183$ \\
\hline Total cost & $76,404,433$ & $73,920,487$ & $175,008,519$ & $214,295,083$ \\
\hline
\end{tabular}

Source: Document of activity plans and budget for several FLL holders in Berau District

commitment to fulfill reclamation obligations than those issued by local governments that tend to have low commitment to fulfill reclamation obligations. This condition is consistent with Zubayr (2014) that the multinational mining company is more compliant with reclamation compared with the local mining company. The response of FLL reclamation by two types of mining permit is described in Table 7.

FLL reclamation institutional development Institutional development is to support better implementation of FLL reclamation and its performance. As explained in previous sections, there are circumstances in the institutional arrangement in terms of transfer of right and jurisdiction boundaries that influence FLL reclamation performance. The institutional arrangement for FLL reclamation in East Kalimantan improvement needs to undertake by:

1. Synchronizing regulations between mining and forestry in reclamation process business, in particular, prompting innovative success criteria as an incentive, coordination among institutions, and regulation to obliterate conflict of interest and transaction cost and to support effective budgeting for human resource and infrastructure improvement; 
Table 6 Progress on forest leasehold license reclamation in East Kalimantan

\begin{tabular}{lcccc}
\hline $\begin{array}{c}\text { District and forest } \\
\text { leasehold license (unit) }\end{array}$ & FLL (ha) & $\begin{array}{c}\text { Disturbed area } \\
\text { (ha) }\end{array}$ & $\begin{array}{c}\text { Reclamation area } \\
\text { (ha) }\end{array}$ & $\begin{array}{c}\text { Revegetation area } \\
\text { (ha) }\end{array}$ \\
\hline Berau (11) & $10,996.76$ & $3,811.09$ & $2,736.99$ & 235.31 \\
Kutai Kartanegara (39) & $39,346.40$ & $7,480.34$ & $3,762.37$ & 434.23 \\
Kutai Timur (12) & $42,809.19$ & $10,112.52$ & $5,871.78$ & - \\
Kutai Barat (22) & $36,662.64$ & $4,429.12$ & 868.72 & 545.16 \\
Paser (4) & $13,840.82$ & $11,555.52$ & $2,140.99$ & - \\
Penajam Paser Utara (2) & 189.08 & 291.39 & 201.51 & - \\
\hline Total (90) & $143,804.89$ & $37,679.98$ & $15,582.36$ & $1,215.20$ \\
\hline
\end{tabular}

Source: Directorate of soil and water conservation, MoEF

Table 7 Response of forest leasehold license reclamation based on the type of mining permit

\begin{tabular}{lccccc}
\hline \multicolumn{1}{c}{ Type of mining permit } & $\begin{array}{c}\text { Disturbed area } \\
\text { (ha) }\end{array}$ & $\begin{array}{c}\text { Reclamation area } \\
\text { (ha) }\end{array}$ & $\begin{array}{c}\text { Revegetation area } \\
\text { (ha) }\end{array}$ & $\begin{array}{c}\text { Assessed area } \\
\text { (ha) }\end{array}$ & $\begin{array}{c}\text { The average score } \\
\text { of response }\end{array}$ \\
\hline Issued by MoEMR & $31,722.56$ & $14,048.97$ & $1,065.06$ & 632.74 & 3 \\
$\begin{array}{l}\text { Issued by East Kalimantan } \\
\text { Government }\end{array}$ & $5,957.42$ & $1,533.39$ & 150.14 & - & 2 \\
\hline Total & $37,679.98$ & $15,582.36$ & $1,215.20$ & 632.74 & 2.5 \\
\hline
\end{tabular}

2. Involvement of FMU in reclamation and mine closure plans assessment in mining and FLL to optimize FLL reclamation utilization and protection;

3. Optimization of reclamation plan through proper evaluation supported by coordination among related stakeholders, enhance evaluator capacity and inserting reclamation business process as a priority in mining permit and FLL issuance with regards to optimum reclamation bond, reclamation, and FLL levy implementations as well as to reduce asymmetric information, adverse selection risk and moral hazard;

4. Synchronizing sanctions regulations against violations among environmental management law, mining law, and forestry law through derivative regulations;

5. Positioning the external institution as CEC involvement and East Kalimantan Supervisory Commission of Mining Reclamation and Post Mining;

6. Presenting MoEF's existence as the mediator in FLL property right enforcement to reduce exclusion cost, free riding, rent-seeking, and opportunism and to create fairness among the parties.

\section{Conclusion}

Transfer of right in the form of FLL is a temporary transfer of the right, but it created permanent negative impact if reclamation was not carried out optimally. Ex-ante and expost in the transfer of right involved multi-stakeholders with various regulations and interests that affected FLL reclamation business process performance. The institutional structure of the FLL reclamation business process as part of the contractual relationship is very complex, with regulation gaps. The institutional structure that interacted with the CPRs character of FLL caused incompatibilities among FLL and
MoEF, community, TUL, and FMU. It triggered high adverse selection risk, transaction costs, coordination disharmony, inefficiency, and moral hazard behavior, both agent and principals. Actors' behavior affected FLL reclamation performance, where permanent reclamation performance only reached $63.67 \%$ with revegetation reached $2.37 \%$. While progressive performance reached $40.80 \%$ and revegetation of $3.25 \%$, this performance is considered able to be improved through the institutional arrangement of FLL reclamation with six substantial improvements steps in East Kalimantan.

\section{References}

Ai-bin, L., Min, Z., \& Ming-yin, L. (2009). Economic analysis and realization mechanism design for full cost of coal mining. Procedia Earth and Planetary Science, 1, 1686-1694. https://doi.org/10.1016/j.proeps.2009. 09.259

Budiawan, A., Kartodihardjo, H., \& Nurrochmat, D. R. (2015). Strategi tenurial pengelolaan hutan lindung: Studi kasus Hutan Lindung Balikpapan. Risalah Kebijakan Pertanian dan Lingkungan, 2(1), 9-16. https://doi.org/10.20957/jkebijakan.v2i1.10362

Chariri, A. (2008). Questioning the popularity of agency theory in accounting research. Jurnal Ekonomi dan Bisnis 14(1), 114.

Creswell, J. W. (2016). Research design: Pendekatan metode kualitatif, kuantitatif, dan campuran (terjemahan). Edisi 4. Yogyakarta: Pustaka Pelajar.

Dalal-Clayton, B., Dent, D., \& Dubois, O. (2003). Rural 
planning in developing countries: Supporting natural resource management and sustainable livelihoods. International Institute for Environment and Development. USA.

[EITI] Extractive Industries Transparency Initiative. (2016). Laporan EITI Indonesia 2016.

Feiock, R. C. (2007). Rational choice and regional governance. Journal of Urban Affairs, 29(1), 47-63.

Fischer, A., Peterson, L., Feldkötter, C., \& Huppert, W. (2007). Sustainable governance of natural resources and institutional change-An analytical framework. Public Administration and Development, 27, 123-137. https://doi.org/10.1002/pad.442

German, L. A., \& Keeler, A. (2010). "Hybrid institutions": Applications of common property theory beyond discrete property regimes. International Journal of the Commons, 4(1), 571-596.

Hein, J. I. (2019). Political ecology of REDD+ in Indonesia agrarian conflicts and forest carbon. New York: Routledge.

Jensen, M., \& Meckling, W. (1976). Theory of the firm: Managerial behavior, agency cost, and ownership structure. Jurnal of Financial Economics, 3(4), 305-360.

Kartodihardjo, H. (1998). Peningkatan kinerja pengusahaan hutan alam produksi melalui kebijaksanaan penataan institusi [dissertation]. Bogor: Institut Pertanian Bogor

Kartodihardjo, H. (2006). Ekonomi dan insttitusi pengelolaan hutan: Telaah lanjut analisis kebijakan usaha kehutanan. Bogor: Penerbit Institute for Deveopment Economics of Agriculture and Rural Areas (IDEALS).

Maharani, R., Susilo, A., Sugiharto, S., \& Fernandes, A. (2010). Revegetasi lahan bekas tambang batubara. Status riset reklamasi bekas tambang batubara. Samarinda: Balai Besar Penelitian Dipterokarpa.

North, D. C. (1990). Institutions, institutional change and economic performance. New York: Cambridge University Press.
Nugroho, B. (2011). Land rights of community forest plantation policy: Analysis from an institutional perspective. Jurnal Manajemen Hutan Tropika, 17(3), 111-118.

Ostrom, E. (1990). Governing the commons: The evolution of institution for collective actions. New York: Cambridge University Press.

Ostrom, E., Gardner, R., \& Walker, J. (1994). Rules, games, and common-pool resources. Michigan: The University of Michigan Press.

Polit, D. F., \& Beck, C. T. (2012). Resource manual for nursing research: Generating and assessing evidence for nursing practice. Wolters Kluwer Health, Lippincott Williams and Wilkins.

Schlager, E., \& Ostrom, E. (1992). Property right regime and natural resources: A conceptual analysis. Journal Land Economics, 68(3) 249-262.

Schmid, A. A. (1987). Property, power, and public choice. An inquiry into law and economics. 2nd ed. New York: Praeger.

Subarudi, Kartodihardjo, H., Soedomo, S., \& Sapardi, H. (2016). Kebijakan resolusi konflik tambang batu bara di Kawasan Hutan di Kalimantan Timur. Jurnal Analisis Kebijakan, 13(1), 53-71.

Theesfeld, I., \& Jelinek, L. (2017). A misfit in policy to protect Russia's black soil region: An institutional analytical lens applied to the ban on burning of crop residues. Land Use Policy, 67, 517-526. https://doi.org/ 10.1016/j.landusepol.2017.06.018

Zhang, J., Rao, Y., Geng, Y., Fu, M., \& Prishchepov, A. V. (2017). A novel understanding of land use characteristics caused by mining activities: A case study of Wu'an, China. Ecological Engineering, 99, 54-69. https://doi. org/10.1016/j.ecoleng.2016.11.026

Zubayr, M. (2014). Implementasi kebijakan penggunaan kawasan hutan untuk pertambangan: Perspekstif hubungan principal-agent [dissertation]. Bogor: Institut Pertanian Bogor. 